\title{
State Corporation Income Taxation An Economic Perspective on Nexus
}

\author{
David E. Wildasin
}

CESIFO WORKING PAPER NO. 3218

CATEgORY 1: PubliC FinANCE

OCTOBER 2010

\footnotetext{
An electronic version of the paper may be downloaded

- from the SSRN website:

- from the RePEc website:

- from the CESifo website:

www.SSRN.com

Www.RePEc.org

www.CESifo-group.org/wp
} 


\title{
State Corporation Income Taxation An Economic Perspective on Nexus
}

\begin{abstract}
Acting in the interest of their residents, within limits imposed by Federal statute and by the Constitution, states have incentives to impose taxes on the profits of corporations owned by nonresidents. This paper presents a model within which a state, using an apportionment formula that includes a sales factor, would choose to tax the income of out-of-state corporations that derive revenues from the sale or licensing of intangible assets to in-state customers, provided that such corporations have sufficient nexus to be taxable. Although such policies enable states to capture rents from nonresidents, they also introduce tax distortions by imposing implicit tariffs on sales by out-of-state firms.
\end{abstract}

JEL-Code: H25, H71, K34.

\author{
David E. Wildasin \\ Martin School of Public Policy \\ University of Kentucky \\ USA - Lexington KY 40506-0027 \\ dew@davidwildasin.us
}

September, 2010

Presented at a conference on "Mobility and Tax Policy: Do Yesterday's Taxes Fit Tomorrow's Economy?”, Oct. 2-3, 2008, at the University of Tennessee, Knoxville, and at the UCLA Tax Policy Workshop,2009. Earlier versions of the research on which this paper is based have been presented at the 1998 Summer Institute for Theoretical Economics on "Interregional Competition in Public Economics", Stanford, CA and at the New York University Tax Law Seminar, 2001. I have benefited from comments by participants at all of these presentations, and by two referees and the editor, but retain responsibility for errors. 


\section{Introduction}

The proper role and scope of state corporation income taxes has been the subject of debate and controversy for at least a half century, and increasingly so in the past decade. States, taxpayers, Congress, and the judicial system have struggled to find a path through the welter of complex legal, business, accounting, and policy questions raised by the efforts of states to tax business incomes in a highly integrated economic system. One crucial question revolves around the issue of "nexus", that is, of determining when a corporation's business activities are "sufficiently connected" to a state that its income can be subject to tax there. Another crucial question concerns how much of a corporation's income is taxable in any given state, a matter that must involve some division or apportionment of the income of multistate corporations. Although to some degree these two issues are conceptually distinct, they are not unrelated in practice because a corporation's economic interactions with a state typically determine not only whether it is taxable there (the nexus question) but also how much of the corporation's income the state will tax (the apportionment question). To take a simple illustrative example, a firm might have the entirety of its plant and employees in one state, and for this reason it could be (and, in practice, would be) considered to have a sufficient nexus there to be taxable. If, however, that state were to apportion a firm's income solely on the basis of its revenues, and if the whole of a firm's revenues derive from out-of-state sales, it would owe no income taxes in its "home state". By contrast, other states would be able to obtain tax revenues from such a firm if they, too, elect to apportion its income in proportion to its sales, but only if its sales in those states are determined to establish nexus there for purposes of income taxation. Other possible apportionment rules - based, for example, on employment rather than sales - would divide taxable income among the states very differently, while other nexus standards for example, a standard that ignores sales and relies entirely on "physical presence" - would assign taxing authority very differently. For the most part, states are under no obligation to select specific nexus or apportionment rules or standards, and their practices diverge significantly in practice. Clearly, the range of possibilities is very great, as is the scope for controversy and confusion.

The goal of the present paper is to shed light on some of the economic and policy consequences of alternative nexus standards and apportionment rules that have been or could be applied by state governments. As may already be apparent, nexus and apportionment rules or policies are very likely to interact with the location of business activity, interstate transactions, and business organizational structure. The distribution of the burden of state corporation income taxes, and their effects on firm organization and interstate commerce, can depend crucially on how nexus is defined and on what basis income is apportioned. These distributional and allocative effects, which determine the ultimate welfare impacts of state corporation income taxes, and thus the benefits and costs of corporation income taxes from the viewpoint of individual states, their residents, and the residents of other states, are the main focus of the analysis presented below.

Before launching into the economic analysis proper, it is useful first to set the stage with a concise review of the institutional and policy background of state corporation income taxation. Section 2 thus discusses the judicial interpretation of constitutional restrictions on state taxing powers, the role that Congress has played in regulating state corporation income tax policy, and evolving state practices regarding nexus and apportionment. Section 3 then presents a series of successively more 
complex models of the taxation of business income in an integrated economic system like that of the United States with many taxing jurisdictions. These models explore the incentives of states to tax business income under different assumptions about nexus standards and apportionment rules, assuming that state governments wish to adopt policies that serve the interests of their residents. The analysis shows that it may be optimal for an individual state to tax the profits of all firms that derive revenues from transactions with customers within the state, even if this is their only economic connection with the state, a policy that is feasible when profits are apportioned in accordance with revenues and under some nexus standards, but not others. However, state corporation income taxation under these conditions results in tariff-like distortions of trade among states and that can harm the overall efficiency of resource allocation in the economy.

Section 4 provides a brief summary and discussion of some of the limitations of the analysis and directions for further research.

\section{Nexus, Apportionment, and Corporate Income Taxation: Courts, Congress, and the States}

In the US federation, the taxing powers of state governments are legally restrained first, by the US Constitution, and second, by Federal statutes. The Constitution's Commerce and Due Process Clauses, in particular, have played a major role in defining the taxing powers of the states. The Commerce Clause states that Congress has the authority to regulate interstate commerce, which has been interpreted to mean that state governments cannot impose policies, such as tariffs on interstate trade, that interfere with interstate commerce. The Commerce Clause has been interpreted to mean that such taxes as states do impose cannot "unduly burden interstate commerce" (Quill Corp. v. North Dakota ). In addition, the Due Process Clause of the Fourteenth Amendment limits the power of a state to tax individuals or businesses without "due process of law", which has been interpreted to mean (again, see Quill) that there must be "some definite link, some minimum connection, between a state and the person, property or transaction it seeks to tax". Under both the Commerce Clause and the Due Process Clause, a business must have a sufficient nexus with a state before it can be subject to tax there. ${ }^{1}$

As indicated by the remarks above, the precise meaning of any constitutional restraints on state taxing powers is determined by the courts, which, in the absence of definitive rulings, can create considerable uncertainty for taxing authorities and for taxpayers alike, and new rulings can trigger significant policy responses. For instance, in 1959, the Supreme Court ruled (Northwestern States Portland Cement Co. vs. Minnesota) that a state could constitutionally tax a portion of the profits

\footnotetext{
${ }^{1}$ For one recent discussion of the Commerce Clause, including the so-called "Dormant" Commerce Clause, see Enrich (2007), who writes (p. 23): "Over the centuries, the Supreme Court has deployed this dormant Commerce Clause hundreds of times to strike down a wide variety of state tax and regulatory measures that were found to impermissibly interfere with the free flow of economic activity in a national common market." For extensive discussion of these matters, including a record of opinions from relevant case law, see Pomp and Oldman (2005) and Hellerstein et al.(2009).
} 
of an out-of-state corporation that solicited sales there, even if it had no plant, employees, or other physical presence or activities within the state. Apparently, this ruling came as a surprise to many, since it spurred nearly immediate Congressional action, in the form of a Federal statute, Public Law (PL)86-272, that specifically prohibits states from imposing corporation income taxes on outof-state businesses if their only contact with a state is that they solicit sales for tangible products there. Congress thus exercised its constitutional power to regulate interstate commerce and, in effect, prohibited by statute state taxes of the type that the Supreme Court had just declared constitutional. This law, which illustrates the potentially important role of Congress in regulating the taxing powers of states, significantly restrains the ability of states to impose taxes on the profits of out-of-state corporations.

Whether by accident or design, PL86-272 leaves open an issue that has come to assume considerable importance. Suppose that a corporation is not physically present in a state, but that it derives revenues from the sale or licensing of intangible services or assets there. These intangible services or assets might, for example, take the form of downloadable software, music, or text, delivered electronically to in-state households or businesses. Alternatively, they might take the form of license fees or royalties paid for the use of trademarks, patents, or copyrighted materials. If a business delivers tangible products to in-state consumers, for instance through mail-order deliveries of books, CDs, or other physical items, its income is not subject to that state's corporation income tax because of PL86-272. However, because the law is silent with respect to intangible goods and services, the power of a state to tax the profits of firms that derive revenues from the sale of intangibles is not directly settled by PL86-272. ${ }^{2}$

In recent years, a number of court cases have addressed the question of whether a state may or may not tax the profits of out-of-state firms that have no physical presence within the state. In one noteworthy case, Geoffrey Inc. v. South Carolina Tax Commission (1993), the Supreme Court of South Carolina ruled that states may indeed impose such taxes. (In this case, a firm outside of South Carolina licensed the trademarks used by retail stores within South Carolina, and the firm was deemed to be subject to South Carolina's corporation income tax.) This issue has been the subject of ongoing litigation and policy reform. ${ }^{3}$ Many states now impose state corporation income taxes on out-of-state firms that derive revenues from the sale of intangibles to in-state buyers, for instance by declaring that any firm that "does business" or that "derives income from sources within the state" is taxable there. ${ }^{4}$ Of course, this "doing business" nexus standard does

\footnotetext{
${ }^{2}$ For convenience, the term "sale" of intangibles will generally be used henceforth as a shorthand for any means by which the owner of an intangible can derive compensation for the right to own or use it, whether by outright transfer of ownership, or through licensing, royalties, or by other means.

${ }^{3}$ As one illustration of the current level of activity in this area, see Boucher and Ponda (2008), who cite court rulings, administrative rulings, and statutory changes related to nexus issues in fifteen different states for the year 2007.

${ }^{4}$ It appears that many practitioners interpret "income" and its "sources" to be closely connected to a firm's revenues but not to its costs. Of course, profits are the difference between revenues and costs and thus are determined by both. For instance, when a corporation buys an input from a vendor in state $A$ rather than state $B$, it does so because this raises its profits, just as is true when it sells a unit of its output to a purchaser in one state rather than another. In both cases, transactions with a counterparty in another state result in increased profits, and thus, as a matter of economic principles, it could be said that both types of transactions are "sources" of the firm's profits.
} 
not yield any taxable income for a state unless it apportions the revenues of multistate corporations in a way that includes the sales of a corporation within the state, and thus the issue of nexus is closely linked to that of income apportionment. The classical "three-factor" formula does so by apportioning the income of a multi-state corporation on the basis of a firm's payroll, property, and sales within a state, with each of these three factors being equally weighted. Few states now adhere to this formula, however, as they increasingly apply a greater weight to the "sales factor" in their apportionment formulae. As noted by Goolsbee and Maydew (2000), as of 1979, the sales factor was overweighted in the apportionment formulae of only 5 states, but this number had grown to more than 20 states by 1995 . Currently, only 9 states apply a $33 \%$ weight to the sales factor, while most others apply weights between $50 \%$ and $100 \%$. Of these, 22 presently use a $50 \%$ weight. Five states now apply a $100 \%$ weight to the sales factor for many or all types of businesses, and several others will transition to a single-factor sales-based apportionment formula within the next several years. ${ }^{5}$ Thus, as a broad characterization, it is fair to say that corporations must pay income taxes in all states where they sell their goods and services, except that they may be exempt from income taxes in states where they export tangible goods, due to PL86-272. The sales factor has come to predominate in the apportionment of the profits of multistate corporations.

These developments raise a number of interesting economic questions. As a matter of economic policy, a basic issue is whether state governments "should" be empowered to tax the profits of outof-state firms, even if they have no physical presence within a state. ${ }^{6}$ To address this question, it is necessary to analyze the economic implications of different nexus standards for state corporation income taxes. The following analysis examines the effects of state corporation income taxes in a series of models that specify the taxing powers of states, and their economic relationship to out-ofstate households and businesses, in different ways. It also examines how states would optimally set

Similarly, it is sometimes said that a business that derives revenue from transactions with parties in a given state has a "definite link" or "minimum connection" to that state because the state's courts could be called upon to help enforce the contracts underlying these transactions, but the same can certainly be said of enforcement of contracts involving purchases from vendors within the state. In short, from an economic perspective, there is little or no basis to distinguish between sales and purchases in determining whether a business is "doing business" within the state or has an "economic presence". To the author's knowledge, no state asserts its power to tax the incomes of out-ofstate businesses that purchase goods or services from vendors within its boundaries. One might guess that states distinguish between purchases and sales in this respect mainly as a matter of export promotion. Similar remarks would apply to the determination of the component factors used for purposes of formula apportionment.

${ }^{5}$ For analyses of the effects of different apportionment formulae, see, e.g. McLure (1980), Gordon and Wilson (1986), Goolsbee and Maydew (2000), and references therein. The present analysis is limited to issues relating to state taxation of business income, but analogous issues certainly arise in the international context. See, e.g, Shackelford and Slemrod (1998) for an analysis of the revenue effects of formula apportionment applied to US multinational firms. It should also be noted that different countries deal with the taxation of business profits for multi-jurisdictional enterprises in different ways. See, e.g., Wildasin (1998, 2000), for some comparison of Canadian and US practices.

\footnotetext{
${ }^{6}$ It is important to distinguish the question of nexus for corporation income tax purposes, which is the topic of the present analysis, from that of nexus for sales taxation. According to the Supreme Court's decision in Quill, outof-state vendors are not subject to state sales taxation. To the degree that the sales tax is viewed as a consumption tax on households, this decision creates substantial administrative obstacles for state policy, only imperfectly offset by the widespread but ineffectual imposition of use taxes. (As noted by Ring (1999), however, state sales taxes fall far short of comprehensive consumption taxes in any case.) For a discussion of recent initiatives for "streamlined" sales taxation, see McLure and Hellerstein (2004). These authors also discuss state corporation income taxation, and criticize proposed Federal statutes that would extend PL86-272 so that nexus, for state income tax purposes, would effectively be based on a physical presence standard.
} 
their corporation income tax policies, assuming that they seek to advance the economic interests of their residents. This involves determining not only what tax rate a state would choose, but whether or not it would wish to include a sales factor in an income-apportionment formula. To anticipate the results, the analysis indicates that states have conflicting incentives to tax the profits of outof-state firms. On the one hand, such taxes may benefit the residents of a state by capturing rents that would otherwise accrue to the owners of out-of-state firms. On the other hand, they can harm the residents of a state by imposing what amounts to an implicit tariff on imports, a policy that is not in itself advantageous to the households residing within a small, open economy. The optimal state tax policy involves a balancing of these two considerations, resulting, in equilibrium, in a nonzero tax on the profits of out-of-state firms. In this equilibrium, interstate trade is distorted, and state corporation income taxes thus give rise to deadweight efficiency losses. This result alone does not determine whether state income taxation of the profits of out-of-state firms is economically desirable, even within the framework of the models developed below, since distributional equity considerations must also be taken into account. The balancing of equity-efficiency tradeoffs and other policy considerations are discussed further in the concluding section.

\section{A Model and Variations}

To see how the effects of corporation income taxes depend on business organization, ownership, and trade, it is convenient to begin with a very simple model and then to vary and extend this model in steps, maintaining a consistent analytical approach and notation. The strategy is to determine, first, what state corporation income tax policy would be chosen by an individual state whose policymakers seek to advance the economic interests of resident households, and then see what happens to an entire system of such states. The equilibrium policies of the states result in an efficient outcome for the system as a whole in some cases but not others. Comparing different cases thus helps to shed light on how different institutional arrangements may or may not facilitate efficient decentralized policymaking, and why.

To begin with, Case 1 considers a situation where firms located within a state may be owned, in part, by non-residents, and where a nexus standard is applied under which only firms located within the state are taxed. Case 2 focuses on situations of central interest. In Case 2a, a state imports goods or services from out-of-state firms but such interstate trade is assumed not to create nexus; thus, as in Case 1, only the profits of firms located within the state are taxable. Case $2 \mathrm{~b}$, on the other hand, considers a broad nexus standard under which the profits of out-of-state firms are considered taxable if they obtain revenues from the sales of intermediate goods within the state, and where income is apportioned based on revenues. Building on these cases, subsection 3.3 considers the incentives for states to apply broad nexus standards and sales-based apportionment rules, with special reference to the taxation of the returns to intangibles that accrue to out-of-state firms.

The analysis is based on an admittedly stylized model that relies on several simplifying assumptions. First, in order to sharpen the focus on the economic interests of the residents of a state taken as a whole, assume throughout that each state contains many identical households who can be 
aggregated into a single representative household, making it possible to ignore possible political conflicts among heterogeneous state residents. Second, assume that each state is small relative to the rest of the economy, so that its policies do not affect equilibrium prices or tax policies elsewhere. Third, in order to abstract from possible inefficiencies arising from other types of taxes, assume that the state may also raise revenues from lump-sum taxes imposed on the representative household. The level of public expenditures is held fixed throughout the analysis, making it unnecessary to specify how state-financed public services affect household utility or private sector production. In this respect, the model is extremely general, which has the advantage of showing that none of the results depend in any way on whether firms benefit from state government expenditures.

\subsection{Case 1: Pure profit taxation and foreign ownership.}

Suppose that there are two sectors or industries, $F$ and $G$, in a given state. Each sector consists of many identical competitive firms operating under conditions of strictly decreasing returns to scale, so that they earn pure profits. ${ }^{7}$ These profits are subject to corporation income taxation at the rate $\tau$. As in a standard Arrow-Debreu economy, the profits of these firms accrue to households in accordance with exogenously-given initial ownership shares. For present purposes, the only analytically important distinction between the $F$ and $G$ sectors is that firms in the former may be owned, in part, by nonresidents, whereas the latter are assumed to be $100 \%$ owned by in-state residents. This distinction is useful because it highlights the importance of nonresident ownership in determining a state's optimal tax policy. Let $\theta \in[0,1]$ denote the ownership share of nonresidents in $F$-sector firms. It is trivial to generalize the model to allow for other industries that operate under conditions of constant returns to scale, but this generalization is omitted for notational simplicity.

Since the firms within a given sector are identical, the notation can be simplified by focusing on a single representative firm in each sector. The production technology in the $F$ sector is represented by a strictly increasing, strictly concave, and smooth function $\phi_{f}\left(l_{f}\right)$ of the amount of primary inputs, represented by a vector $l_{f}$. This input vector may be interpreted as labor (possibly of many types), land, natural resources, or any other factors of production. Similarly, the production technology in the $G$ sector is represented by a well-behaved production function $\phi_{g}\left(l_{g}\right)$. At this stage of the analysis, the variable inputs are all non-traded factors of production, fixed in supply for the state as whole in the form of an endowment $\bar{l}$, owned entirely by residents within the state, so that

$$
l_{f}+l_{g}=\bar{l} .
$$

The competitively determined factor price vector for primary inputs is denoted by $w$. The prices of the outputs of both sectors are normalized at unity. ${ }^{8}$ The gross (before-tax) profits of firms in

\footnotetext{
${ }^{7}$ This means, of course, that business profits in this analysis are "firm specific" and not "location specific". Location-specific rents can and do arise in the model, and are represented by the returns to locationally-fixed resource such as labor or natural resources, as described below.

${ }^{8}$ One possible interpretation is that both outputs are perfectly substitutable in consumption, units are chosen so that their relative price is one, and either is then taken as numéraire. As a second interpretation, the outputs of both sectors are traded on external markets at prices that are taken as parametrically given from the perspective of
} 
each sector are thus given by

$$
\pi_{i}=\phi_{i}\left(l_{i}\right)-w l_{i} \quad i=f, g
$$

Firms choose their inputs to maximize profits net of tax, for which the first-order conditions are

$$
\phi_{i l}\left(l_{i}\right)-w=0 \quad i=f, g,
$$

where $\phi_{i l}$ denotes the partial derivatives of the production function, i.e., the marginal products of the inputs $l_{i}$. Equations (1) and (3) determine the equilibrium values of $\left(w, l_{f}, l_{g}\right)$ independently of the tax rate $\tau$. As expected, state taxation of pure profits has no effect on input or output choices, nor does it affect factor prices. Clearly, and as expected, the burden of the state corporation income tax falls on the owners of firms. This implies, in particular, that some of the burden of the tax is borne by nonresidents, in proportion to their ownership of firms in the $F$ sector.

As noted above, the state government is assumed to provide some exogenously-fixed bundle of public goods and services, the cost of which is denoted by $G$. Assuming that the state may impose a lump-sum tax of $T$ on state residents in addition to taxes on business profits, the state government budget constraint is

$$
T+\tau\left(\pi_{f}+\pi_{g}\right)=G
$$

Finally, given that public goods levels are fixed, it is clear that the utility of the representative state resident depends on state tax policy only through its effects on private good consumption. This, in turn, is equal to the household's income net of tax, which is determined by its income from ownership of primary inputs plus its share of after-tax business profits, as given by

$$
Y=w \bar{l}+(1-\tau)\left(\left[(1-\theta] \pi_{f}+\pi_{g}\right)-T+\bar{Y}=w \bar{l}+\pi_{f}+\pi_{g}-\theta(1-\tau) \pi_{f}-G+\bar{Y} .\right.
$$

where $\bar{Y}$ represents any other exogenously-fixed sources of income that may be received by the state's residents and the second equality follows by substitution from (4). ${ }^{9}$

Assuming that state policymakers choose the rate of taxation $\tau$ in the interest of the state's representative household, they seek to maximize $Y$. Given the fact that factor prices, allocations, and gross profits are unaffected by the rate of tax, it follows that

$$
\frac{d Y}{d \tau}=\theta \pi_{f} \geq 0
$$

and the inequality is strict, provided that $\theta>0$. Hence:

Proposition 1: Provided that nonresidents own a positive share of profit-making firms within the state, the optimal state corporation income tax rate is $100 \%$.

a small state. In this case, the profits of the firms in these sectors are assumed not to be subject to taxation in other states.

${ }^{9}$ In particular, $\bar{Y}$ may include any net income that the households in this state derive from their share of ownership of firms located in other states. Given that each state is assumed to be small, any such income may be treated as exogenously fixed from the viewpoint of any one state. 
This straightforward result highlights the importance of foreign ownership of the firms in a state. A pure profits tax captures rents that would otherwise accrue to the owners of profit-making firms. If some of these owners do not reside within the state, the imposition of a tax on profits allows the state to transfer some of these rents from nonresidents to residents. Within the strict confines of the model as developed so far, such rent transfers do not give rise to any allocative consequences: the imposition of state corporation income taxes affects the distribution of income among households in the economy but does not give rise to any deadweight losses from inefficient resource allocation. Even if every state were to impose such taxes, and thus effectively confiscate some portion of the income that would otherwise accrue to residents of other states, these taxes would not result in an inefficient outcome for the economy as a whole.

Of course, in practice, there are many reasons why state corporation income taxes might produce significant inefficiencies. These could arise from the fact that corporation income taxes fall not only on pure profits but on other types of income (such as the normal return to capital). The deadweight losses resulting from such taxes have been amply discussed elsewhere and need not be examined further here. ${ }^{10}$ In addition, it should perhaps be emphasized that policies that transfer rents give rise to incentives for rent-losers to lobby against them. In the present instance, although businesses cannot influence the political process directly through voting, they might have incentives to expend resources to limit the extent of rent transfers through state tax policies. These activities can also be socially costly. The following analysis abstracts from such considerations, which however may well warrant separate study.

As a final remark, it is worth considering whether and under what circumstances a state is or should be constitutionally permitted to impose taxes directly on the nonwage income of nonresident households. From an economic standpoint, in the model presented above, the incentive for a state to impose a tax on corporations derives precisely from the fact it allows for a portion of the state's tax burden to be shifted to nonresident owners, and in fact is equivalent in its economic effects to a direct tax on the share of business net income received by nonresidents. Such a direct tax on nonresidents might be open to legal challenge on constitutional grounds.

\subsection{Case 2: Pure profit taxation with foreign ownership and traded inputs}

In the preceding case, issues relating to the apportionment of corporation income do not arise. This is because firms are assumed to operate only within the boundaries of a single state, with the possible exception that they may derive revenues from out-of-state sales which, by assumption, could not make them subject to tax elsewhere. Now consider the case where interstate transactions do occur. In particular, suppose that firms in the $F$ sector, in addition to using non-traded primary inputs $l_{f}$ in the production process, also use a vector of tradeable intermediate inputs $m$ that they import from out-of-state firms. Let $p$ denote the price at which this input is purchased by firms in the $F$ sector. The production function for this sector is now written as $\phi_{f}\left(l_{f}, m\right)$ and profits in

\footnotetext{
${ }^{10}$ See Wilson (1999), Wilson and Wildasin (2004), and Wildasin (2006) for introductions to the literature on fiscal competition, containing many references to other studies.
} 
this sector are given by

$$
\pi_{f}=\phi_{f}\left(l_{f}, m\right)-w l_{f}-p m
$$

Let $M$ denote the total output of the out-of-state producers of the intermediate inputs, so that $M-m$ represents intermediate inputs sold to firms in other states, at a price denoted by $\bar{p}$. The profits of the out-of-state producers of intermediate inputs are given by

$$
\pi_{m}=p m+\bar{p}(M-m)-c(M)
$$

where $c(M)$ is the cost function for these producers.

\section{Case 2a: No nexus for intermediate goods producers}

To begin, suppose that the out-of-state producers of intermediate goods are not subject to taxation in states to which they export, for instance because these states do not include a sales factor in their apportionment formulas, because courts declare such taxation to be unconstitutional, or because Federal statutes, such as PL86-272, prohibit such taxation.

Since the export of the intermediate good has no tax consequences for its producers, these firms will only export the intermediate good to states in which their products can be sold at a price as high as that obtainable elsewhere. Hence, it must be the case in equilibrium that $p=\bar{p}$, provided that $0<m<M .{ }^{11}$ The net income of the representative household in an importing state is still given by (5), with the understanding that $\pi_{f}$ is given by (7) and where $p=\bar{p}$ is treated as parametrically fixed on external markets. In this case, the analysis of the optimal choice of the state's corporation income tax rate $\tau$ is essentially unchanged, and we have

Proposition 2a: If a state cannot or does not tax the profits of out-of-state producers of intermediate goods, Proposition 1 continues to hold. That is, provided that nonresidents own a positive share of profit-making firms within the state, the optimal state corporation income tax rate is $100 \%$.

This unsurprising result merely confirms that the introduction of trade with out-of-state firms does not in itself affect a state's optimal corporation income tax policy.

\section{Case 2b: Single-factor sales-based apportionment}

Now consider what happens when a state imposes a tax on the profits of the out-of-state producers of intermediate inputs. This can happen if some of the profits of those firms are apportioned to the states to which they export. To simplify the algebra and to obtain the most clear-cut results, assume that states use only the sales factor to apportion the profits of firms in other states. ${ }^{12}$ Under

\footnotetext{
${ }^{11}$ If $m=0$, the model effectively reduces to the previous case. If $m$ is an essential input for downstream producers, however, $0<m<M$ is guaranteed to hold in equilibrium.

${ }^{12}$ The basic results of the following analysis continue to hold if states apportion income using other factors, such as employment or capital investment, in addition to sales. However, it is essential that a sales factor be used as at least one factor in the apportionment of income. If not, it is immaterial whether an out-of-state firm deriving revenues
} 
these conditions, profit-making out-of-state firms that sell products to in-state firms (or households) incur positive tax liabilities. Specifically, the importing state can impose its corporation income tax on the share

$$
\sigma=\frac{p m}{p m+\bar{p}(M-m)}
$$

of the profits of the intermediate goods producing firms. Since sales of the intermediate good now results in a tax on these firms, the price of their products within the local market, $p$, must be sufficiently high to compensate for these tax liabilities - that is, the price $p$ will depend on the state's corporation income tax rate $\tau$, rising as the tax rate rises. As will become clear, this adverse change in the "terms of trade" - i.e., an increase in the price of an imported commodity - must be taken into account in determining a state's optimal tax policy.

This relationship is most easily calculated in the simple special case where the cost of production of intermediate inputs is zero, i.e., $c(M) \equiv 0$, so that the profits of intermediate good producers are equal to their total revenues. ${ }^{13}$ In order to convey the essential insights of the analysis in the simplest fashion, the following discussion imposes this strong simplifying assumption. However, the key result - specifically, Proposition $2 \mathrm{~b}$ below - continues to hold in the more general case where production costs are positive, as shown in the Appendix.

When there are no production costs, the gross profits of intermediate goods producers are just equal to their revenues, $p m+\bar{p}(M-m)$, and their after-tax profits are

$$
\begin{aligned}
\pi_{m}^{*} & =(1-\sigma \tau-[1-\sigma] \bar{\tau}) \pi_{m} \\
& =(1-\sigma \tau-[1-\sigma] \bar{\tau})(p m+\bar{p}[M-m]) \\
& =(1-\tau) p m+(1-\bar{\tau}) \bar{p}(M-m)
\end{aligned}
$$

where $\bar{\tau}$ denotes the corporation income tax rate imposed in other states. The intermediate goods producers choose $m$ to maximize their profits, the first-order condition for which is

$$
(1-\tau) p=(1-\bar{\tau}) \bar{p}
$$

From (11), it follows that the intermediate input price is higher, the higher the rate of tax; in particular,

$$
\frac{d p}{d \tau}=\frac{(1-\bar{\tau}) \bar{p}}{(1-\tau)^{2}}=\frac{p}{(1-\tau)}>0
$$

This result illustrates the fact (see, e.g., McLure (1980)) that a corporation income tax is, implicitly, a tax on those items that are used to apportion profits. In the present case, profits are apportioned on the basis of sales alone, and the corporation income tax is thus, in part, a tax on the importation of traded intermediate inputs. A small state cannot depress the net price received by firms that

from sales within a state, but with no other presence there, is considered to have nexus; even if the nexus threshold is passed, none of the firm's income will be taxable and the firm will have no liability, so the nexus issue becomes irrelevant.

\footnotetext{
${ }^{13}$ Under this simplifying assumption, the intermediate good may be thought of as a fixed endowment, for instance of some natural resource.
} 
export to it. An increase in the state's corporation income tax rate must therefore give rise to a compensatory increase in the price of imports, as shown in (12).

As before, the welfare of a state's representative household is determined by its net of tax income, which is now

$$
Y=w \bar{l}+\pi_{f}+\pi_{g}-\theta(1-\tau) \pi_{f}+\tau \sigma \pi_{m}+\bar{Y}-G=w \bar{l}+\pi_{f}+\pi_{g}-\theta(1-\tau) \pi_{f}+\tau p m+\bar{Y}-G .
$$

To calculate the effect of state tax policy on net income, it is now necessary to take into account the fact that $p$ depends on $\tau$. As a result, the level of imports, the amount of employment and output in each sector of the state's economy, the profits of firms in both sectors, and the prices of primary inputs may all be affected by the choice of $\tau$. Using the envelope theorem,

$$
\begin{aligned}
\frac{d Y}{d \tau} & =\left(\bar{l}-l_{f}-l_{g}\right) \frac{d w}{d \tau}-m \frac{d p}{d \tau}-\theta \frac{d(1-\tau) \pi_{f}}{d \tau}+p m+\tau m \frac{d p}{d \tau}+\tau p \frac{d m}{d \tau} \\
& =-\theta \frac{d(1-\tau) \pi_{f}}{d \tau}+\frac{\tau}{1-\tau} p m \epsilon_{m}
\end{aligned}
$$

where the second equality follows by using (1) and (12) and where $\epsilon_{m} \equiv d \ln m / d \ln p<0$ is the general equilibrium elasticity of $m$ with respect to $p$. The state's optimal policy is to choose $\tau$ to maximize $Y$, which implies that

$$
\frac{\tau}{1-\tau}=\frac{\theta}{p m \epsilon} \frac{d(1-\tau) \pi_{f}}{d \tau}
$$

The first term in (14), which is positive so long as an increase in $\tau$ reduces net profits, represents the burden imposed on nonresident owners of $F$-sector firms resulting from an increase in $\tau$. The second term, which is negative if $\tau>0$, represents the welfare loss from the distortion of trade in intermediate inputs. From (15) it is clear that the optimal state policy is to set $\tau=0$ if $\theta=0$, so as to avoid the distortion from the implicit tariff that the corporation income tax imposes on imports. This result confirms, for this particular context, the classical finding that free trade is optimal for a small open economy. More generally, however, if nonresidents own a share of firms in the $F$ sector, then it is optimal for the state to impose at least a modest corporation income tax in order to capture some of the profits in that sector that would otherwise flow to nonresidents. It is also clear from (15) that a tax rate of $100 \%$ cannot be optimal. Thus:

Proposition 2b: If a state uses a single-factor sales-based apportionment formula, it is optimal for the state to impose a corporation income tax at a positive rate of less than $100 \%$, provided that nonresidents have a positive ownership share of profit-making firms within the state. An optimal corporation income tax rate balances the marginal gain from the capture of rents from nonresidents against the welfare loss to state residents from increased distortions of trade in imports.

Three additional remarks about this result are in order.

First, when a state chooses its optimal tax rate, i.e., when it chooses that value of $\tau>0$ such that $d Y / d \tau=0$, it distorts the efficiency of resource allocation in the economy as a whole, producing a 
deadweight welfare loss. This is in contrast to the situation in Case 1, where the state corporation income tax allows a pure transfer of rents from nonresident to resident households. It is also in contrast to Case 2a, where trade does occur but the state does not tax the apportioned profits of out-of-state firms. In the present case, there is a first-order welfare gain for the state's residents from the introduction of at least a small corporation income tax, but the first-order welfare loss from trade distortions, starting at $\tau=0$, is zero. Thus, states have incentives to introduce policies that are socially inefficient.

Second, it is interesting to note that the state corporation income tax now achieves economic effects that are equivalent to those that would result from a combination of a state tax on the incomes of non-residents plus a tariff on imports from other states. As noted above, a direct tax on nonresident incomes might be challenged on constitutional grounds, and the second, if implemented directly, might be viewed as a violation of the Commerce Clause. Thus, from an economic viewpoint, a state corporation income tax, when combined with an apportionment formula based on sales, may be viewed as a blend of two policies, each of which, if implemented in a "naked" form, might be considered unconstitutional.

Third, note that taxation of the profits of the out-of-state producers of intermediate inputs based on a single-factor sales-based apportionment rule is a second-best policy from the viewpoint of a taxing state, and from the viewpoint of the ensemble of all states. Individual states would ideally tax only the profits of foreign-owned firms operating within their boundaries and would avoid the trade distortions arising from the taxation of the profits of out-of-state firms, which could be achieved by declaring profits to be taxable only for firms operating within the state, as in Cases 1 and 2a. Such an outcome does arise if liability for state corporation income taxes is based on a "physical presence" nexus standard, and it would also be the case if states were to apportion income for tax purposes solely on the basis of factors like payroll and capital that do not depend on sales within the state. ${ }^{14}$

\subsection{State corporation income taxes and business organization}

The analysis so far has highlighted some reasons why states might wish to tax the income of corporations when, as is the case in practice, some portion of that income accrues to nonresidents. This is true even when states use inclusive nexus standards, as in Case $2 \mathrm{~b}$, under which the profits of out-of-state firms are also taxable when a sales-based apportionment factor is used. As just remarked, however, this policy is less than ideal from the viewpoint of an individual state, since it distorts trade and harms the welfare of the residents of the taxing state. This implication of the model seems inconsistent with the trends, noted in Section 2, toward reliance on broad nexus standards and heavy use of sales factors in apportionment formulae.

\footnotetext{
${ }^{14}$ Under the OECD Model Income Tax Treaty for the taxation of the income of multinational corporations, as well as Canada's system of provincial taxation of multi-province corporations, a corporation's income is taxable in jurisdictions where it has "permanent establishments". Application of such a standard appears to exempt a corporation's income from taxation in the absence of a "physical presence".
} 
To see why states have incentives to do this, recall that the benefit of corporation income taxes, in the models considered so far, is entirely dependent on foreign ownership of profit-making firms that operate entirely within the state - the firms in the $F$ sector. Although these firms may possibly sell their output outside of the state, their production processes occur entirely within the state. The nonresident owners of these firms would desire, if possible, to avoid the tax burdens of state corporation income taxation. To do this, suppose that a corporation is organized, or reorganized, in such a way that ownership of some or all of the crucial assets that give rise to its profits can be separated from the ownership of the assets that are used in the firm's operations within a given state, and suppose that the ownership of these assets is embodied in some intangible claim. For instance, in the preceding analysis, the firms in the $F$ sector are assumed to derive pure profits from their operations in a state, perhaps because each has made some innovation, built a reputation, or depends upon some entrepreneurial skill that generates a net return over and above the cost of the firm's primary and intermediate inputs.

Suppose that the ownership of these underlying assets can be embodied in intangible assets, such as trademarks, patents, or copyrights, and that the ownership of these assets can be transferred (with no tax consequences) to out-of-state households or firms; alternatively, suppose that these assets "originate" or are created outside of the state, and that the $F$-sector firms then use these assets to produce their outputs. To avoid distractions, assume initially that there is some other state where the returns to these intangible assets escape taxation. ${ }^{15}$ In either case, the services of these assets can be utilized within the state by in-state firms by paying royalties, licensing fees, or other compensation for them. Suppose that the value of this compensation is equal to the profits that would otherwise accrue to the $F$-sector firms within the state, thus reducing their profits to zero. With out-of-state ownership of these intangible assets, and assuming either that only in-state firms are taxable, or that the incomes of out-of-state firms are apportioned without reference to any sales factor, a state's corporation income tax can no longer capture the rents that would otherwise have been taxable as the profits of the firms in the $F$ sector. In terms of the analysis of Cases 1 and 2 above, this form of business or industrial structure in effect causes the $F$ sector to vanish from the model: under the postulated nexus/apportionment policy, there are no profits accruing to nonresidents that the state can tax. The corporation income tax ceases to be a mechanism that can benefit a state's residents.

On the other hand, suppose that a state implements a nexus standard under which it can tax outof-state firms that derive revenues from sales within the state, including revenues that derive from use of intangible assets, as was the case in South Carolina in the circumstances of the Geoffrey case. Suppose in addition that income is apportioned in proportion to sales. In this case, the situation is as described in the model of Case 2b. The net income of in-state residents is given by (13), where the term $\pi_{f}$ represents the return to the ownership of intangible assets utilized in the $F$ sector, now postulated to be taxable. In addition, the apportioned profits of out-of-state suppliers of intermediate inputs are included in the state corporation income tax base.

\footnotetext{
${ }^{15}$ In the US, Delaware, the home of Geoffrey, largely exempts such income from tax. Romano (1997) discusses the rather unique role and circumstances of Delaware in the competition for corporate charters. Although Delaware's tax treatment of intangibles may play some role in this competition, other states also offer a favorable corporation income tax environment; for instance, Nevada, South Dakota, Texas, and Washington presently have no corporation income taxes at all.
} 
In the special case where the state imports no intermediate goods or services other than the right to utilize these intangible assets, the model of Section $2 \mathrm{~b}$ effectively reduces to that of Case 1, and the net income of state residents is given by (5). In this special case, the optimal state policy is to tax corporation income at a rate of $100 \%$, as shown in Proposition 1 , but its interpretation is different: it now describes the optimal tax policy for a state that taxes the profits of out-of-state firms that license intangible assets to in-state firms, assuming that there are no other imports to the state.

In the more general case where the state does import other intermediate inputs, as of course is true empirically for every state in the highly integrated US economy, the results of Case $2 \mathrm{~b}$ apply. Once again, however, the interpretation is different. The firms in the $F$ sector located within the state no longer have any taxable profits, as they must pay out-of-state firms for the use of intangibles. Using a broad nexus standard and a sales-based apportionment rule, however, the amount $\pi_{f}$ is still part of the state's tax base, where this amount is now understood to be the returns accruing to the out-of-state owners of intangible assets. Under the postulated nexus and apportionment policies, the sales-apportioned profits of out-of-state suppliers of all other intermediate inputs are taxable as well. Proposition $2 \mathrm{~b}$ and (15) describe the optimal state tax policy in this case. As noted in that context, the equilibrium of such a system entails deadweight welfare losses due to the distortion of interstate trade.

In short, states do have incentives to adopt broad nexus standards and sales-based apportionment formulae when these provide a means by which to capture some part of the rents that would otherwise accrue to nonresident owners of the returns to intangible assets. This rent capture comes at the cost, however, of trade distortions.

The preceding discussion has proceeded on the assumption that intangible assets can be transferred to a state where the returns to these assets are not taxed. In fact, however, this assumption is inessential. So long as corporation income tax rates are not equal everywhere, there is a tax advantage to business and industrial structures in which the returns to intangibles accrue to businesses located in low-tax states, and one may presume that such structures tend to emerge in equilibrium. The preceding theoretical analysis does not assume symmetry among states, and in the realistic setting of Case $2 \mathrm{~b}$ there is no reason to expect that tax rates are the same everywhere - as indeed they are not, in practice. In any case, for whatever tax or nontax reasons out-of-state owners of intangible assets may exist, it is in the interest of any one state to use a broad nexus standard and to use a sales factor to apportion income in order to capture rents that would otherwise escape taxation. This policy calculus is unaffected by the choice of tax rates in other states, and depends only on the assumption that returns to intangibles used within a state flow to asset owners in other states. $^{16}$

\footnotetext{
${ }^{16}$ Just as Delaware has established a preferential tax regime for corporations that derive income from intangible assets, other states could conceivably do the same. The establishment of such a regime would be superfluous, of course, in those states that do not tax corporation incomes in any case. In any event, when courts (as in Geoffrey) uphold the power of other states to tax such income (via a sales factor, combined with a broad nexus standard), the tax advantage of such tax preferences is substantially attenuated or eliminated altogether, perhaps explaining why other states do not create special tax preferences like that found in Delaware.
} 
One might wonder whether this mechanism of rent capture [deletion] via state corporation income taxes could be defeated by a somewhat more complex form of industrial organization. To illustrate, let us consider a three state example, in which a rent-generating intangible asset is created by some individual such as an engineer, author, or artist, located in state $A$. This asset will ultimately be of value to firms operating in state $C$. If the creator of the asset forms a corporation and licenses its intangible assets directly to licensees in state $C$, that state could capture a portion of the rents that would otherwise accrue to the creator of the asset, as just described, using a broad nexus standard and sales-based income apportionment. Suppose instead, however, that the corporation that holds the intangible asset sells ownership of the asset to another corporation, located in state $B$, and that this corporation in $B$ now licenses the product to licensees in state $C$. In other words, a new owner, the corporation in state $B$, is now interposed between the creator of the asset and the licensees in state $C$. Assuming that the asset is sold (or licensed) at its proper market price to the corporation in state $B$, that corporation's (economic) profits will be zero: the fees it receives for the licensing of the asset by users in state $C$ will be just sufficient to compensate for the asset's purchase. In this case, state $C$ will obtain zero revenue from the taxation of the corporation in state $B$. To capture rents from the original creator of the asset, state $C$ would need to tax the sale of the asset by the creator of the intangible asset in state $A$ to the corporation in state $B$. On constitutional grounds, it may be doubtful whether state $C$ would possess the power to tax such transactions. ${ }^{17}$

Indeed, as this example suggests, the "transactional distance" between the ultimate user of an intangible asset, such as a final consumer, and the original creator of the intangible asset, such as an inventor, may be arbitrarily long, as (say) an inventor sells an idea to a corporation that produces a product that is purchased by some other corporation that sells its products or services to some other corporation, and so on, until finally a household consumes a product whose price reflects, in part, the value of the original invention. Such a "transaction chain" (see Wildasin (2000), 438, and (2002), 184, 187) for related discussion) may separate the original owner of a profit stream from a taxing jurisdiction by many more than just three states.

Still, even long transactions chains may not protect nonresident owners of profit-producing assets from taxation by "downstream" states. In the simple three-state example above, the ability of the original asset owner in state $A$ to escape the burden of a tax imposed in state $C$ depends on the (implicit) premise that the sale of the rights to that asset to a corporation in state $B$ is not taxable by state $B$. In fact, within the confines of the model above, state $B$ would have an incentive to impose such a tax. If it does, then it is state $B$, and not the further downstream state $C$, that is able to capture the rent from the creator of the asset. In fact, the formal analysis presented above already incorporates just this case; it merely needs to be interpreted to apply at one stage further "upstream".

\footnotetext{
${ }^{17}$ See Altshuler and Grubert (2009) for related discussion.
} 


\section{Conclusion}

The preceding analysis has examined the economic implications of state corporation income taxation under varying assumptions about nexus standards, formula apportionment, and business structure. It has highlighted the potential of a corporation income tax to transfer rents to the residents of a state at the expense of nonresident owners of in-state businesses. To the extent that businesses can be structured so that these rents accrue to nonresident owners of intangible assets such as patents, trademarks, and copyrights, however, a state corporation income tax with a standard based on physical presence, or with an apportionment formula that does not include a sales factor, cannot capture these rents. If sales within a state suffices to establish nexus, and if income is apportioned with sales as one or perhaps the only apportionment factor, a portion of these rents can once again be captured through the state corporation income tax. Implemented in this way, however, the corporation income tax imposes an implicit tariff on imports from other states, distorting interstate trade and generating deadweight efficiency losses.

In principle, the normative evaluation of tax policy should be concerned not only with matters of allocative efficiency but with distributional issues as well. The distributional effects of state corporation income taxes are not easily ascertained, however. Within the models presented above, such taxes redistribute rents among households in different states in accordance with the degree of cross-ownership of claims on profit-making assets. From a distributional perspective, they would thus seem, on balance, to transfer resources away from states where households own a large fraction of the nation's wealth. ${ }^{18}$ The empirical difficulties involved in determining the net degree of crossownership of profit-producing assets among households residing in different states are formidable, and there seems to be little evidence on the basis of which one could even hazard an informed conjecture about the net interstate transfers produced by state corporation income taxes. ${ }^{19}$ Furthermore, from an overall social perspective, the degree to which state policies ought to be evaluated in terms of their distributional impacts is somewhat debatable; according to one influential perspective on fiscal federalism, the tasks of the "distributional branch" of the public sector should in any case be assigned to the national government, with subnational governments focusing primarily or even exclusively on promoting allocative efficiency (see, e.g., Oates (1972), for discussion and references). In sum, it is difficult to see a substantial basis, on equity grounds, in favor of any particular nexus standard for state corporation income taxes.

It goes without saying that the foregoing analysis has neglected many potentially important di-

\footnotetext{
${ }^{18}$ Departing from the "representative agent" framework, and recognizing that wealth is unequally distributed among households, state taxes on business profits would transfer resources from wealthy to less-wealthy households. For the issues at stake in the present context, however, the intrastate distribution of income is of secondary importance; different nexus standards "matter" insofar as they affect the distribution of tax burdens among households in different states.

${ }^{19}$ In a general-equilibrium setting, of course, the policies undertaken in one state affect the entire constellation of equilibrium prices for all goods and factors throughout the entire economy (Bradford 1978). A computable generalequilibrium analysis could conceivably be used to evaluate the implications of changes in nexus standards for business profits taxes, either for a single state or for all states taken together, provided that data could be found that would permit a meaningful calibration of a CGE model.
} 
mensions of state corporation income taxes. In some respects, the analysis bears a resemblance to that presented in Wildasin and Wilson (1998), in which cross-ownership of resources produces incentives for decentralized governments to engage in confiscatory taxation; in that analysis, such policies remove the potential efficiency gains from the pooling of independent risks arising in different jurisdictions. The preceding analysis has abstracted from these or any other risk-pooling considerations. The analysis has also ignored the possibility that the economic activities of corporations, whether or not they benefit from public goods and services provided by states, may impose costs on states through congestion or other external effects (see Pogue, 2007, who also draws attention to equity issues related to cross-ownership of multistate firms). In general, such effects provide a rationale for taxes or non-tax charges on business activities on firms that are physically present within a jurisdiction, but out-of-state vendors of intangibles do not produce such effects and would not be taxed on such grounds. The suitability of corporation income taxes as an instrument for internalizing congestion or external costs is questionable, in any case, since such effects may well be produced both by firms that make profits and by those that do not.

Still other complications may arise from the mismeasurement of corporate profits for tax purposes, such that state corporation income taxes distort firm financial structures, investment and employment decisions, organizational forms, and other types of economic behavior; the preceding analysis, by postulating that corporate profits are correctly measured and are used as the basis for taxation, abstracts from these complications. In addition, the foregoing analysis has assumed that firms in the economy are perfectly competitive and exercise no appreciable market power. Clearly, the welfare implications of alternative tax policies may be quite different in an economy with monopolistic, oligopolistic, or monopolistically competitive firms. Finally, as noted earlier, taxation of economic rents creates incentives for lobbying activities which may give rise to deadweight welfare losses insofar as these are inherently costly or to the extent that they distort policies in ways that introduce additional distortions. Further analysis of these issues, some of which have already been examined in previous research, goes beyond the scope of the present paper.

\section{References}

Altshuler, R. and H. Grubert (2008), "Formula Apportionment: Is It Better than the Current System and Are There Better Alternatives?", Oxford University Centre for Business Taxation Working Paper 09/01.

Boucher, K. J. and S. Ponda (2008), "Current Corporate Income Tax Developments (Part I)", The Tax Adviser March, 2008.

Bradford, D.F. (1978), "Factor Prices May Be Constant But Factor Returns Are Not." Economics Letters 1, 199-203.

Enrich, P.D. (2007), "A Defense of the Commerce Clause's Role in Constraining State Business Tax Incentives," National Tax Association, Proceedings of the 99th Annual Conference (2007), 22-29. 
Goolsbee, A. and E. L. Maydew (2000), "Coveting thy neighbor; ${ }^{-}$s manufacturing: the dilemma of state income apportionment," Journal of Public Economics, 75 (1), 125-143.

Hellerstein, W., K. Stark, J. Swain, and J. Youngman (2009), State and Local Taxation: Cases and Materials, 9th ed. (Thomson West).

McLure, C.E., Jr. (1980), "The State Corporate Income Tax: Lambs in Wolves' Clothing," in H. Aaron and M. Boskin, (eds.), The Economics of Taxation (Washington: Brookings).

McLure, C.E., Jr. and W. Hellerstein (2004), "Congressional Intervention in State Taxation: A Normative Analysis of Three Proposals," State Tax Notes 31, 721/

Oates, W.E. (1972) Fiscal Federalism (New York: Harcourt Brace Jovanovich).

Pomp, R.D. and O. Oldman (2005), State and Local Taxation, 5th ed. (Hartford: R.D. Pomp).

Pogue, T.F. (2007), "The Gross Receipts Tax: A New Approach to Business Taxation?" National Tax Journal 60, 799-819.

Ring, R.J. Jr. (1999), "Consumers' Share and Producers' Share of the General Sales Tax", National Tax Journal 52, 79-90.

Romano, R. (1997), "State Competition for Corporate Charters", in J. Ferejohn and B.R. Weingast (eds.), The New Federalism: Can the States Be Trusted (Stanford: Hoover Institution Press), 129154 .

Shackelford, D. and J. Slemrod (1998), "The Revenue Consequences of Using Formula Apportionment to Calculate U.S. and Foreign-Source Income: A Firm-Level Analysis," International Tax and Public Finance 5, 41-59.

Wildasin, D.E. (2000), "State and Provincial Corporation Income Taxation: Current Practice and Policy Issues for the US and Canada," Canadian Tax Journal 48, 424-441.

Wildasin, D.E. (2002), "Tax Coordination: The Importance of Institutions," Swedish Economic Policy Review 9(1), 171-194.

Wildasin, D.E. (2006) "Fiscal Competition", in B. Weingast and D. Wittman (eds.), Oxford Handbook of Political Economy (Oxford: Oxford University Press), 502-520.

Wildasin, D.E. and J.D. Wilson (1998), "Risky Local Tax Bases: Risk-Pooling vs. Rent Capture," Journal of Public Economics 69, 1998, 229-247.

Wilson, J.D. (1999), "Theories of Tax Competition", National Tax Journal 52, 269-304. 
Wilson, J.D. and D.E. Wildasin (2004), "Capital Tax Competition: Bane or Boon?", Journal of Public Economics 88, 1065-1091. 


\section{Appendix}

The proof of Proposition $2 \mathrm{~b}$ in Section 2.2 is extended here to cover the case where out-of-state producers of intermediate inputs incur non-zero costs of production. The basic strategy of the analysis is as before. The first task is to relate the rate of corporate profits taxation to the price of the intermediate input, by analogy to (12). The second is to determine how a change in tax policy affects the welfare of a state's residents, taking all effects, including this induced change in price, into account, by analogy to (14).

The gross profits of intermediate good producers are given by (8) and their net profits are shown in the first line of (10). These producers choose total output $M$ and the portion of their output to sell in the importing state $m$ to maximize net profits. Assuming an interior solution, the choice of $m$ must satisfy the first-order condition

$$
\frac{\partial \pi_{m}^{*}}{\partial m}=(1-\tau) p-(1-\bar{\tau}) \bar{p}+(\tau-\bar{\tau}) \tilde{p} \frac{C}{R}=0
$$

where $\tilde{p} \equiv(1-\sigma) p+\sigma \bar{p}$ is a weighted average of prices within and outside of the state and where $C \equiv c(M)$ and $R \equiv(p-\bar{p}) m+\bar{p} M$ denote, respectively, the production costs and the revenues of the intermediate goods producing firms. ${ }^{20}$ Note that $C / R<1$ because intermediate goods producers earn positive profits.

A small state cannot reduce the net profits of an out-of-state producer of intermediate inputs because its policies cannot reduce the profitability of sales in other regions. Thus, the price $p$ must adjust as the tax rate $\tau$ changes to leave $\pi_{m}^{*}$ unchanged, implicitly defining a relationship between the tax rate $\tau$ in the importing state and the price $p$ in that state at which the out-of-state firm is willing to sell within the state. Expressed concisely,

$$
\frac{d p}{d \tau}=-\frac{\partial \pi_{m}^{*} / \partial \tau}{\partial \pi_{m}^{*} / \partial p}
$$

Using the envelope theorem, it is straightforward to show that this expression is positive. (It reduces to (12) when $C=0$.)

Turning now to the objective function for state policymakers, the net income of the representative resident is given by

$$
Y=w \bar{l}+\pi_{f}+\pi_{g}-\theta(1-\tau) \pi_{f}+\tau \sigma \pi_{m}+\bar{Y}-G
$$

as in (13). Determining the impact of $\tau$ on $Y$ requires calculating the derivative of the term $\tau \sigma \pi_{m}$ in this expression with respect to $\tau$.

To simplify this calculation, note that a small change in $\tau$ has no effect on the profits of the outof-state intermediate input producers, since the price $p$ must adjust to insure that it is equally profitable for these firms to sell their product within and outside of the state. Given that $\bar{\tau}$ and $\bar{p}$

${ }^{20}$ The derivation of this equation uses $\partial \sigma / \partial m=\tilde{p} / R$. 
are invariant to changes in $\tau$, this means that $d \pi_{m}^{*} / d \tau=0$, taking all equilibrium adjustments into account, i.e. ${ }^{21}$

$$
\begin{aligned}
\frac{d \tau \sigma \pi}{d \tau} & =\frac{d \pi}{d \tau}(1-[1-\sigma] \bar{\tau})+\bar{\tau} \pi \frac{d \sigma}{d \tau} \\
& =(1-[1-\sigma] \bar{\tau}) m \frac{d p}{d \tau}+(p-\bar{p})(1-[1-\sigma] \bar{\tau}) \frac{d m}{d \tau}+\bar{\tau} \pi\left([1-\sigma] \frac{m}{R} \frac{d p}{d \tau}+\frac{\tilde{p}}{R} \frac{d m}{d \tau}\right)
\end{aligned}
$$

Collecting terms and simplifying, the terms involving $d m / d \tau$ reduce to

$$
\tau\left(p-\tilde{p} \frac{C}{R}\right) \frac{d m}{d \tau}
$$

so that

$$
\frac{d \tau \sigma \pi}{d \tau}=m \frac{d p}{d \tau}-(1-\sigma) \bar{\tau} m\left(1-\frac{\pi}{R}\right) \frac{d p}{d \tau}+\tau\left(p-\tilde{p} \frac{C}{R}\right) \frac{d m}{d \tau}
$$

With this result, it follows that

$$
\frac{d Y}{d \tau}=-\theta \frac{d(1-\tau) \pi_{f}}{d \tau}+(1-\sigma) \bar{\tau} m\left(\frac{C}{R}\right) \frac{d p}{d \tau}+\tau\left(p-\tilde{p} \frac{C}{R}\right) \frac{d m}{d \tau} .
$$

Note first that this expression reduces directly to (14) in the special case where $C=0$, as expected.

For the more general case where production costs are positive, since the expression $p-\tilde{p}(C / R)$ is positive ${ }^{22}$ and since $d p / d \tau$ is positive, it follows that the optimal value of $\tau$ is positive given that $\bar{\tau} \geq 0$. This means that a state will impose a positive tax on corporate profits. As discussed earlier with reference to Proposition $2 \mathrm{~b}$, however, the profits tax indirectly taxes imports, and, as before, the optimal value of $\tau$ is thus limited by trade distortions, as reflected by the last term in (A.7). The equilibrium for the entire system of states is one in which non-zero taxes are imposed everywhere and in which the efficiency of resource allocation is distorted, provided that there is cross-ownership of profit-making firms. This establishes Proposition $2 \mathrm{~b}$ for this more general case.

\footnotetext{
${ }^{21}$ To derive the second line of (A.4), note that $d \pi / d \tau=\partial \pi / \partial \tau+(\partial \pi / \partial p)(\partial p / \partial \tau)+(\partial \pi / \partial m)(\partial m / \partial \tau)=$ $m(\partial p / \partial \tau)+(p-\bar{p})(\partial m / \partial \tau)$. Also note that $d \sigma / d \tau=(\partial \sigma / \partial p)(\partial p / \partial \tau)+(\partial \sigma / \partial m)(\partial m / \partial \tau)=(1-\sigma)(m / R)(\partial p / \partial \tau)+$ $(\tilde{p} / R)(\partial m / \partial \tau)$

${ }^{22}$ To demonstrate this, use the first-order condition (A.1). If $\tau \geq \bar{\tau}$, (A.1) implies that $p \geq \bar{p}$, and hence $p \geq \tilde{p}>$ $(C / R) \tilde{p}$. If $\tau<\bar{\tau}$, use (A.1) to show (after simplification) that $* \tau-\bar{\tau})(p-\tilde{p} C / R)=(p-\bar{p})(1-\bar{\tau})$, which again proves the desired result.
} 


\section{CESifo Working Paper Series}

for full list see www.cesifo-group.org/wp

(address: Poschingerstr. 5, 81679 Munich, Germany, office@cesifo.de)

3156 Franziska Tausch, Jan Potters and Arno Riedl, Preferences for Redistribution and Pensions. What can we Learn from Experiments?, August 2010

3157 Martin Kolmar and Andreas Wagener, Inefficient Group Organization as Optimal Adaption to Dominant Environments, August 2010

3158 Kai Carstensen, Klaus Wohlrabe and Christina Ziegler, Predictive Ability of Business Cycle Indicators under Test: A Case Study for the Euro Area Industrial Production, August 2010

3159 Horst Rottmann and Timo Wollmershäuser, A Micro Data Approach to the Identification of Credit Crunches, August 2010

3160 Philip E. Graves, Appropriate Fiscal Policy over the Business Cycle: Proper Stimulus Policies Can Work, August 2010

3161 Michael Binder and Marcel Bluhm, On the Conditional Effects of IMF Program Participation on Output Growth, August 2010

3162 Michael Binder, Qianying Chen, and Xuan Zhang, On the Effects of Monetary Policy Shocks on Exchange Rates, August 2010

3163 Felix J. Bierbrauer, On the Optimality of Optimal Income Taxation, August 2010

3164 Nikolaus Wolf, Europe’s Great Depression - Coordination Failure after the First World War, September 2010

3165 Dan Kovenock and Brian Roberson, Conflicts with Multiple Battlefields, September 2010

3166 Jean-Pierre Ponssard and Catherine Thomas, Capacity Investment under Demand Uncertainty. An Empirical Study of the US Cement Industry, 1994-2006, September 2010

3167 Jørgen Juel Andersen, Jon H. Fiva and Gisle James Natvik, Voting when the Stakes are High, September 2010

3168 Michael Hoel, Is there a Green Paradox?, September 2010

3169 Scott Alan Carson, Nineteenth Century US African-American and White Female Statures: Insight from US Prison Records, September 2010

3170 Gil S. Epstein, Yosef Mealem and Shmuel Nitzan, Political Culture and Discrimination in Contests, September 2010 
3171 Sara Fisher Ellison, Jeffrey Greenbaum and Wallace P. Mullin, Diversity, Social Goods Provision, and Performance in the Firm, September 2010

3172 Silvia Dominguez-Martinez, Randolph Sloof and Ferdinand von Siemens, Monitoring your Friends, not your Foes: Strategic Ignorance and the Delegation of Real Authority, September 2010

3173 Marcus Dittrich and Beate Schirwitz, Union Membership and Employment Dynamics: A Note, September 2010

3174 Francesco Daveri, Paolo Manasse and Danila Serra, The Twin Effects of Globalization - Evidence from a Sample of Indian Manufacturing Firms, September 2010

3175 Florian Blöchl, Fabian J. Theis, Fernando Vega-Redondo and Eric O’N. Fisher, Which Sectors of a Modern Economy are most Central?, September 2010

3176 Dag Morten Dalen, Marilena Locatelli and Steinar Strøm, Longitudinal Analysis of Generic Substitution, September 2010

3177 Armin Falk, Stephan Meier and Christian Zehnder, Did we Overestimate the Role of Social Preferences? The Case of Self-Selected Student Samples, September 2010

3178 Christian Fahrholz and Cezary Wójcik, The Bail-Out! Positive Political Economics of Greek-type Crises in the EMU, September 2010

3179 Klaus Abberger and Wolfgang Nierhaus, The Ifo Business Cycle Clock: Circular Correlation with the Real GDP, September 2010

3180 Walter Krämer and Gerhard Arminger, “True Believers” or Numerical Terrorism at the Nuclear Power Plant, September 2010

3181 Bernard M.S. Van Praag, Dmitri Romanov and Ada Ferrer-i-Carbonell, Happiness and Financial Satisfaction in Israel. Effects of Religiosity, Ethnicity, and War, September 2010

3182 Dimitrios Koumparoulis and Paul De Grauwe, Public Capital, Employment and Productivity: An Empirical Investigation for Greece, September 2010

3183 John Whalley and Tanmaya Shekhar, The Rapidly Deepening India-China Economic Relationship, September 2010

3184 Andreas Schäfer and Thomas Steger, History, Expectations, and Public Policy: Economic Development in Eastern Germany, September 2010

3185 Thomas Eichner and Marco Runkel, Subsidizing Renewable Energy under Capital Mobility, September 2010

3186 Konstantinos Angelopoulos and James Malley, Fear of Model Misspecification and the Robustness Premium, September 2010 
3187 Philip E. Graves, A Note on the Design of Experiments Involving Public Goods, September 2010

3188 Glenn Ellison, How does the Market Use Citation Data? The Hirsch Index in Economics, September 2010

3189 Barbara Hanel and Regina T. Riphahn, The Employment of Mothers - Recent Developments and their Determinants in East and West Germany, September 2010

3190 Alexander Haupt and Silke Uebelmesser, Integration, Mobility, and Human Capital Formation, September 2010

3191 Vincenzo Galasso and Paola Profeta, When the State Mirrors the Family: The Design of Pension Systems, September 2010

3192 Stéphane Zuber and Geir B. Asheim, Justifying Social Discounting: The RankDiscounted Utilitarian Approach, September 2010

3193 Alexander Kemnitz, Educational Federalism and the Quality Effects of Tuition Fees, September 2010

3194 Claudia M. Buch, Sandra Eickmeier and Esteban Prieto, Macroeconomic Factors and Micro-Level Bank Risk, September 2010

3195 May Elsayyad and Kai A. Konrad, Fighting Multiple Tax Havens, September 2010

3196 Laszlo Goerke and Markus Pannenberg, Trade Union Membership and Dismissals, September 2010

3197 Ferdinand Mittermaier and Johannes Rincke, Do Countries Compensate Firms for International Wage Differentials?, September 2010

3198 John Boyd, Gianni De Nicoló and Abu M. Jalal, Bank Competition, Asset Allocations and Risk of Failure: An Empirical Investigation, September 2010

3199 Guido Heineck and Bernd Süssmuth, A Different Look at Lenin’s Legacy: Trust, Risk, Fairness and Cooperativeness in the two Germanies, September 2010

3200 Ingvild Almås, Tarjei Havnes and Magne Mogstad, Baby Booming Inequality? Demographic Change and Earnings Inequality in Norway, 1967-2000, October 2010

3201 Thomas Aronsson and Sören Blomquist, The Standard Deviation of Life-Length, Retirement Incentives, and Optimal Pension Design, October 2010

3202 Thorvaldur Gylfason and Eduard Hochreiter, Growing Together: Croatia and Latvia, October 2010

3203 Ken Burdett and Melvyn Coles, Tenure and Experience Effects on Wages: A Theory, October 2010 
3204 Wendy Carlin, Good Institutions are not enough: Ongoing Challenges of East German Development, October 2010

3205 Tobias König and Andreas Wagener, Tax Structure and Government Expenditures under Tax Equity Norms, October 2010

3206 Daniel W. Sacks, Betsey Stevenson and Justin Wolfers, Subjective Well-Being, Income, Economic Development and Growth, October 2010

3207 Mario Larch and Wolfgang Lechthaler, Why "Buy American” is a Bad Idea but Politicians still Like it, October 2010

3208 Guglielmo Maria Caporale and Luis A. Gil-Alana, US Disposable Personal Income and Housing Price Index: A Fractional Integration Analysis, October 2010

3209 Bruno S. Frey, Withering Academia?, October 2010

3210 Eva Mörk, Anna Sjögren and Helena Svaleryd, Childcare Costs and the Demand for Children - Evidence from a Nationwide Reform, October 2010

3211 Dan Kovenock, Brian Roberson and Roman M. Sheremeta, The Attack and Defense of Weakest-Link Networks, October 2010

3212 Shmuel Nitzan and Kaoru Ueda, Prize Sharing in Collective Contests, October 2010

3213 Erling Eide, Kristine von Simson and Steinar Strøm, Rank Dependent Utility, Tax Evasion and Labor Supply, October 2010

3214 Thomas Eichner and Marco Runkel, Interjurisdictional Spillovers, Decentralized Policymaking and the Elasticity of Capital Supply, October 2010

3215 Susan Athey and Glenn Ellison, Dynamics of Open Source Movements, October 2010

3216 Christian Bjørnskov, Axel Dreher, Justina A.V. Fischer and Jan Schnellenbach, Inequality and Happiness: When Perceived Social Mobility and Economic Reality do not Match, October 2010

3217 Thomas Cornelissen, Oliver Himmler and Tobias Koenig, Fairness Spillovers - The Case of Taxation, October 2010

3218 David E. Wildasin, State Corporation Income Taxation - An Economic Perspective on Nexus, October 2010 